Pakistan Journal of Humanities and Social Sciences

July - September 2018, Volume 6, No. 3, Pages 338 - 356

\title{
Poverty Reduction and Stock Market Development: Evidence from Africa
}

\author{
Bamanga Umar ${ }^{1}$, Sabri Nayan ${ }^{2}$ \\ ${ }^{1}$ Department of Banking and Finance, School of Management and Information Technology, \\ Modibbo Adama University of Technology, Yola - Nigeria \\ ${ }^{2}$ School of Economics, Finance \& Banking, Universiti Utara Malaysia \\ Email: bamanga32@gmail.com
}

\begin{abstract}
Despite the increased number of stock exchanges in Africa, this segment of the financial market remains underdeveloped with low market capitalization, volume and illiquidity. Furthermore, the aftershock of the 2008 financial crisis exacerbates the poor market condition with the attendant decrease in investment. Efforts of previous policies to promote stock market development and restore investors' confidence did not yield a positive outcome as they are yet to meet the rising demand for capital needed by domestic firms. This paper examines the relationship between poverty reduction and stock market development in Africa, using the pooled mean group (PMG) model for the sample period of 1996 to 2016. The findings suggest poverty reduction has a positive effect on stock market development both in the long-run and short-run estimates. For policy prescription, the government of the respective countries should implement programs that will promote financial inclusion and alleviate poverty to promote domestic investment in stock markets in the region.
\end{abstract}

Keywords: Africa, Financial market, PMG model, Poverty reduction, Stock market development

JEL Classification Codes: G12, G21, G32, E43

\section{Introduction}

Although stock markets assist in promoting economic activities, they are affected by conditions of other economic variables. The capital markets, especially in small open economies play a vital role in mobilizing financial resources to attain greater success in market development. Despite Asiri and Abdalla (2015) affirm that stock markets provide facilities that allow companies to raise capital at lower cost and make them less dependent on bank financing, the African stock markets do not contribute significantly on financial intermediation. Similarly, Asiedu and Afful (2014) observe that Africa is one of the most 
underdeveloped continents because most of the countries are not likely to meet the UNDP Millennium development goals.

Moreover, the socioeconomic factors would have been a major setback to the development and growth of the African financial system. The unrelenting level of poverty in the continent that has an adverse effect on economic growth could have contributed to low investment and the overall low development of the stock market in the region. The recent report from World Bank states that Sub Sahara Africa is a home of at least 30 percent of World poorest people and Africa has six out of the ten most unequal countries in the World (World Bank Group, 2015). In fact, the scourge of poverty and unemployment has ravaged almost all nations in different dimensions (Akwara et al., 2013).

Despite the significant increase of the number of stock exchanges established in the African region, Allen et al (2011) posit that a mere creation of stock exchange is of limited value devoid of an enabling environment for the smooth functioning of the markets. Additionally, Ahuru and Olaposi (2016)state that in spite of policy agenda to open African financial market to foreigners, the performance of stock markets in African countries is below expectation. The reason is not farfetched as stock markets in emerging economies like African countries are facing serious challenges regarding market capitalization, the volume, and liquidity. According to Beck et al (2004), the financial breadth and depth in Africa are the lowest in all regions of the world while Allen et al (2011) note that the African stock markets face serious challenges regarding market depth.

Due to the underdevelopment of the stock market in most African nations, investors are reluctant in bringing their capital to the region without a promising future return. According to Massa (2009), investor's confidence in African stock market is continuously degrading and it may not be unconnected to traditional barriers of stock market development like the small size, low liquidity, lack of transparency and inadequate infrastructure. In fact, the challenge for most African capital markets is to increase liquidity and have sufficient breadth and depth to ensure price efficiency (Hearn \& Piesse, 2010).

Furthermore, the global financial crisis of 2008 is one of the major factors that exacerbate investors panic and led to a significant decline in their investment in the region. In spite the evidence that external finance is necessary to augment domestic saving to accelerate investment (Asiedu, 2002), the global financial crisis in 2008 has led to a substantial decline in import, export and foreign investment inflow to Africa with a consequential loss in market capitalization. Ali and Afzal (2012) affirm that the net capital inflow from advanced to the 
emerging nations declines significantly from the beginning of the crises. Although the crisis was originated in the United States, it spreads to almost all nations with varying degree of damages. Iqbal (2010), states that despite the developing economies are not responsible for the financial crises, they are seriously affected by the channels of trade and finance. These factors create uncertainty in the minds of investors and if not addressed will further aggravate the threat on African investment. Beck et al (2011) observe that the African capital markets experienced a rapid decline in capital flows which dampens the stock market indexes and constrained the government and firms to cancel the bond and stock issues.

Table 1: Trends of Stock Market Development

\begin{tabular}{|c|c|c|c|c|c|c|}
\hline \multirow{2}{*}{ Year } & \multicolumn{3}{|c|}{ AFRICA } & \multicolumn{3}{c|}{ MALAYSIA } \\
\cline { 2 - 7 } & $\begin{array}{c}\text { Average } \\
\text { MK }\end{array}$ & $\begin{array}{c}\text { Average } \\
\text { STV }\end{array}$ & $\begin{array}{c}\text { Average } \\
\text { TOR }\end{array}$ & MK & STV & TOR \\
\hline $\mathbf{1 9 9 6}$ & 24.3 & 2.06 & 6.77 & 303.56 & 25.42 & 8.38 \\
\hline $\mathbf{1 9 9 7}$ & 26.26 & 3.01 & 8.97 & 93.22 & 42.59 & 45.68 \\
\hline $\mathbf{1 9 9 8}$ & 25.7 & 4.22 & 8.66 & 132.42 & 36.79 & 27.79 \\
\hline $\mathbf{1 9 9 9}$ & 27.8 & 5.41 & 10.54 & 176.77 & 53.13 & 30.06 \\
\hline $\mathbf{2 0 0 0}$ & 26.05 & 6.06 & 10.25 & 120.65 & 55.99 & 46.41 \\
\hline $\mathbf{2 0 0 1}$ & 21.27 & 5.9 & 11.3 & 128.23 & 22.67 & 17.68 \\
\hline $\mathbf{2 0 0 2}$ & 21.66 & 5.92 & 8.45 & 124.72 & 25.51 & 20.45 \\
\hline $\mathbf{2 0 0 3}$ & 26.37 & 6.07 & 8.4 & 145.93 & 41.48 & 28.42 \\
\hline $\mathbf{2 0 0 4}$ & 31.67 & 6.52 & 9.63 & 145.59 & 43.44 & 29.84 \\
\hline $\mathbf{2 0 0 5}$ & 38.35 & 8.67 & 11.61 & 125.77 & 31.1 & 24.73 \\
\hline $\mathbf{2 0 0 6}$ & 45.77 & 12.73 & 15.94 & 144.8 & 42.5 & 29.35 \\
\hline $\mathbf{2 0 0 7}$ & 56.92 & 17.4 & 17.51 & 168.07 & 79.9 & 47.54 \\
\hline $\mathbf{2 0 0 8}$ & 53.16 & 19.44 & 18.14 & 81.99 & 35.67 & 43.5 \\
\hline $\mathbf{2 0 0 9}$ & 44.38 & 17.39 & 16.83 & 142.99 & 39.97 & 27.95 \\
\hline $\mathbf{2 0 1 0}$ & 44.47 & 12.89 & 12.11 & 160.26 & 45.01 & 28.09 \\
\hline $\mathbf{2 0 1 1}$ & 39.14 & 10.09 & 12.14 & 132.78 & 43.74 & 32.92 \\
\hline $\mathbf{2 0 1 2}$ & 43.92 & 6.35 & 8.07 & 148.38 & 39.32 & 26.5 \\
\hline $\mathbf{2 0 1 3}$ & 47.78 & 6.8 & 7.29 & 154.79 & 43.98 & 28.41 \\
\hline $\mathbf{2 0 1 4}$ & 47.51 & 7.82 & 8.98 & 135.77 & 42.2 & 31.08 \\
\hline $\mathbf{2 0 1 5}$ & 44.07 & 7.96 & 8.75 & 129.19 & 37.61 & 29.1 \\
\hline $\mathbf{2 0 1 6}$ & 40.63 & 8.11 & 8.51 & 121.33 & 33.14 & 27.01 \\
\hline $\mathbf{5 0 1 6}$ & & & & & \\
\hline
\end{tabular}

Source: World Bank and Financial Development and Structure Databases.

In addition, due to abject poverty, most Africans struggle to meet their basic necessity of life and do not have means of investing which becomes a serious stumbling block to investment. Similarly, available statistics reveal that about 67 to 70 percent of Africans reside 
in rural areas with limited infrastructure and most of them are in abject poverty. In fact, Africa is the only region that did not meet the millennium development goal of halving poverty by 2015 (Beggle et al., 2016). This is a serious risk to the development and prosperity of the region that needs adequate attention. In addition, the table below made a comparison of the nature of stock market development in the selected African countries and Malaysia.

The figures in the table reveal that all the major indicators of market development in Africa are far below what is obtainable in the non-African emerging market. For example, the highest ratio of average market capitalization (MK) in Africa was 56.92 in 2007. However, the Malaysian market capitalization for the same year was 168.07 representing about $300 \%$ above the African average. Also, the average stock traded (STV) in Africa or market liquidity in 2016 was 8.11 which is four times lower than the Malaysian figure of the same year while the average market turnover ratio (TOR) is 8.51 compared to 27.01 in Malaysia. This confirms the prior literature that stated the region faces serious challenges regarding market size, volume and liquidity which makes it difficult if not impossible to provide long-term financing.

This paper makes a valuable contribution to the financial market literature in several ways. First, the prior literature has been silent about the possible impact of poverty reduction on stock market development despite Beck et al (2007) suggest that poverty reduction may stimulate demand for financial services. Hence this paper bridge the literature gap by providing empirical evidence that poverty reduction has a positive impact on stock market development. To the best of knowledge, this finding is new evidence in the financial market literature. Intuitively when poverty level is reduced drastically, the household will have access to finance while their income beyond consumption can be invested in the stock market to provide more investment opportunities for firms and businesses. The second contribution is on the fact that the stock market development is multidimensional with alternative proxies for measuring the different aspect of the market. Most of the previous studies (Law and Tan, 2009; Aduda et al., 2012; Chipaumire \& Ngirande, 2014; Arize et al., 2017) do not identify the flaw of using a single proxy though Levine (2005) confirms the weakness of single proxy to represent stock market development. This paper overcomes this issue and constructed a composite index using principal component analysis (PCA) that captures market capitalization, the stock traded and turnover ratio. Thirdly, the paper considers structural break due to the 2008 global financial crisis and findings suggest its negative impact on 
market development. This paper examines the effect of poverty reduction on stock market development in selected African countries using the pooled mean group (PMG) model.

The remaining part of the paper is organized in the following order: section two reviews theoretical and empirical literature, section three describes data and methodology, section four discusses empirical finding while section five is for conclusion and policy implications.

\section{Literature Review}

Although the existing security market theories do not suggest precise factors predicting the variation of the stock market, the Arbitrage Pricing Theory (APT) of Ross (1976) is the most suitable asset pricing theory that links stock market to multiple risk factors. The theory suggests that securities return is a function of investment sensitivity to several common factors. This signifies that several risk factors can be used to explain changes in the stock market and the APT assumption is that securities returns are derived through the following linear model:

$$
\boldsymbol{r}_{\boldsymbol{t}=\boldsymbol{\gamma}_{\boldsymbol{t}}+\boldsymbol{\beta}_{t} \boldsymbol{\delta}+\varepsilon_{\boldsymbol{t}}}
$$

Where $r_{t}$ denotes market return on asset $t, y_{t}$ is the intercept or unconditional expected return, $\beta_{\mathrm{t}}$ symbolizes coefficient measuring the impact of each factor on the securities return, $\delta$ is a vector of several risk factors while $\varepsilon$ is error term for the residuals or white noise. Poverty is a critical factor that is so pervasive in the African region with more than half of the population living below the poverty line becoming serious setback retarding domestic investment. If poverty level and other associated socioeconomic factors are addressed, the Africans would have an opportunity to safe out of their income and can be translated to investment in stock markets to yield more returns in the long-run. Poverty is considered among the crucial factors affecting households, firms and economic development. Beck et al., (2004) observe that countries with well-developed financial intermediaries experience a speedy reduction in poverty. Moreover, the recent report from World Bank states that Sub Sahara Africa is a home of at least 30 percent of World poorest people and Africa has six out of ten most unequal countries in the World (World Bank Group, 2015). In fact, the scourge of poverty has ravaged almost all nations on the continent in different dimensions.

Although there are no existing studies on the impact of poverty reduction on the stock market, this paper reviews the effect of financial development on poverty reduction. There is substantial evidence suggesting inverse relationship between financial development and poverty reduction (Beck et al., 2004; Honohan, 2004; Clarke et al., 2006; Lazar et al 2006; 
Demirgüç-Kunt \& Levine, 2009; Odhiambo, 2009; Batuo et al, 2010; Khan et al., 2011; Boukhatem, 2016; Blau, 2017). Therefore it can be said that when countries attain a certain level of financial development, finance can be extended to the poor households which will go a long way at improving the standard of living, economic stability and poverty reduction.

Moreover, other empirical literatures consider the possibility of financial development benefiting only the rich and well-connected individuals in a society through income inequality (Kunieda et al., 2014; Jauch \& Watzka, 2015; Adams et al, 2016). The positive relationship cannot be unconnected to uneven access to financial services between the rich and the poor as the rich get richer and the poverty level becomes unacceptably high. The second reason may be that most of the financial intermediaries prefer investment in riskless asset giving less priority to individual and firms financing request. Additionally, Sun et al. (2013) assert that a poor household with tight financial constraints could not invest in their children education leading to inter-generational poverty. Therefore increasing access to financial resources will magnify economic prospects for less privileged to fund investment of their children.

Furthermore, there are empirical kinds of literatures reporting a non-linear relationship between the variables. For example Rashid and Intartaglia (2017), Kim and Lin (2011), and Beck et al (2007) suggest that the financial development can reduce poverty only when there are strong regulatory and institutional frameworks while Rewilak (2017) found that financial deepening has contributed significantly in providing access to finance for the poor. Similarly, Prete (2013) uncovers the effect of financial development on poverty reduction is driven by economic literacy. The ability to explore new investment opportunities will indisputably lead to poverty reduction signifying investors' competence as one of the critical factors resulting in the success of business operations. By contrast, Dhrifi, (2013); Naceur and Zhang (2016) and Odhiambo (2010) uncover that it is the financial development and savings that contribute to poverty reduction. On the other hand, the studies of Akhter and Daly (2009) and Jeanneney and Kpodar (2008) disclose the beneficial effect of financial development on poverty reduction is hampered through financial instability. Their argument is that when the financial system is unstable, it results in fluctuation in the price of goods and investments both are threats to market stability and development.

Despite empirical evidences of significant relationship, other studies suggest financial development has no significant impact on poverty reduction and inequality (Seven \& Coskun, 2016; Donou, 2016; Das \&Mohapatra, 2003; Perez-Moreno, 2011; Fowowe \& 
Abidoye, 2012; Tan \& Law, 2012). These studies emphasize that inactive financial markets hamper growth opportunities and amplify the scourge of poverty. Secondly, despite structural adjustment programs result to rise in demand for financial services in developing countries, this request has not been well considered by the financial market to supply finance in proportion to the increase in demand.

Moreover, some empirical studies focus on how economic growth influences poverty reduction in different aspects. In terms of the development agenda, the continent of Africa has been left behind as the level of income is inadequate to overcome the rising trend of poverty. Collier (2007) asserts that the reduction of poverty in Africa is to a greater extent dependent on intensifying African growth. The question of which economic activity is capable of mitigating poverty generally depends on the sector recording the growth. There are studies that found the agricultural sector as a major contributing factor to poverty reduction (Montalvo \& Ravallion, 2010; Ivanic \& Martin, 2017; Mellor \& Malik, 2017). Similarly, social protection is found to be vital in mitigating the adverse effect of poverty in the crisis period (Kiendrebeogo et al., 2017), demographic change through increase in number of working population increase per capita growth and lessens poverty rate (Ahmed \& Cruz, 2016), income growth is a major determinant for increase/decrease of poverty level in developing countries (Fosu, 2017) while another study found the service sector growth has a significant impact on poverty reduction than the industrial and agricultural sectors(Ferreira et al., 2010).

The question of whether poverty reduction will help promote stock market development has not been considered in the prior literature. On a general note, the previous studies were conducted on how financial development contributes to the poverty reduction. Thus this paper contributes to filling the existing literature gap by providing empirical support that poverty reduction matter for stock market development. In other words, this study extends this line of research by looking at reverse causation as to how poverty reduction contributes to the development of African stock markets. The findings provide evidence by answering a policy question of whether poverty reduction can improve financial market development. Needless to say, an understanding empirical link between poverty reduction and stock market development will let policymakers assess whether poverty level in Africa is a contributing factor to the low development of stock markets. 


\section{Data and Methodology}

To examine how poverty reduction relates to stock market development in selected African countries, this paper obtains data from the World Development Indicators (WDI) databank of 2016 and the Financial Development and Structure database developed by Beck et al. (2010). The annual sample data for the 12 African countries start from 1996 to 2016 and this gives 252 numbers of observations. The selected countries based on data availability are Côte d'Ivoire, Egypt, Ghana, Kenya, Malawi, Mauritius, Morocco, Namibia, Nigeria, South Africa, Uganda and Zambia. Moreover, a composite index was constructed for stock market development incorporating market capitalization, the stock traded and stock turn over. Similarly, the household final consumption expenditure was used to proxy for poverty reduction. The paper controls the poverty reduction-stock market development relationship with some number of variables including banking development, exchange rates, interest rates and structural break. To check for the structural break, a dummy of 1 was used to stand for break dates and 0 for the pre-crisis period to capture the impact of structural change on the African stock markets.

However, this paper expects a theoretical link between stock market development and the selected variables. The paper theorizes a positive relationship between poverty reduction and stock market development. For control variables of the model,, the paper assumes a positive relationship between banking development-stock market while other control variables of exchange rate and interest rates are expected to exert negative impact based on previous empirical findings (Pradhan et al., 2014; Moya-Martínez et al, 2015; Amarasinghe, 2016).

The Pooled mean group (PMG) model of Pesaran et al. (1999) was employed to investigate the relationship between poverty reduction and stock market development. This technique (PMG) has several advantages over the traditional models. Due to common features of the African economies, the model is suitable as the similarity is expected to impact on the long-term parameters in a similar way. Also, it has the additional advantage over the other heterogeneous models by constraining long-run estimates to be similar irrespective of the order of integration of the variables. Lastly, the estimates of PMG seem quite robust to misspecification bias, outliers and lag order selection. The study specifies equation 1 as an initial model for this study which incorporates the dependent variable, independent variable and a set of control variables as follows: 


$$
S M D_{i t}=\alpha_{0}+\alpha_{1} P V R_{i t}+\alpha_{2} B D_{i t}+\alpha_{3} E X R_{i t}+\alpha 4_{4} I R_{i t}+\alpha 5 B R K_{i t}+\varepsilon_{i t}
$$

Where SMD stands for stock market development, PVR is for poverty reduction, BD is a symbol of banking development, IR represents interest rates, ER symbolizes exchange rates and BRK stand for structural change. The epsilon $\varepsilon$ means error term, whereas $i$ represent country and $t$ denotes a period of time. However, $\mathrm{i}=1,2,3 \ldots 12$ is for the selected African countries while $t=1,2,3 \ldots . .21$ is for the number of years to be covered. Therefore, the unrestricted PMG model specification is shown below:

$$
S M D_{i t}=\sum_{n=1}^{r} \theta_{i j} S M D_{i, j-e}+\sum_{n=1}^{s} \gamma_{i j}^{\prime} C_{i, g-1}+\delta_{i}+\varepsilon_{i t}
$$

Where SMD is the dependent variable representing stock market development, $x_{i, t-j}$ is the vector of explanatory variables (Poverty reduction, Banking sector development, Exchange rates, Interest rates and Break) for country $i$. The subscript, $t=1,2,3 \ldots$ T for time $t$ and $i=1,2,3 \ldots \mathrm{N}$, for countries in the sample. The symbol $\delta_{i}$ represents country- specific effects while $\mu_{i}$ denotes fixed effect parameterization. Similarly, the Equation can be rewritten as VECM model as follows:

$$
\Delta S M D_{i t}=\gamma i\left(S M D_{i t=} M K_{i, t-1}-\partial_{i}^{\prime} \mathrm{C}_{i, g-e}+\delta_{i}+\varepsilon_{i t}\right)+\sum_{n=1}^{r-1} \theta_{i j} \Delta \rho_{i, g-e}+\sum_{n=1}^{s-1} \gamma_{i j}^{\prime} \Delta \mathrm{C}_{i, g-e}+\varepsilon_{i t}
$$

Where $\gamma i$ represents the error correction term coefficient and $\delta$ i represents long-run parameters, which are assumed to be common across entities. The primary interest is the speed of adjustment, $\gamma i$ and coefficient of long-run estimates. The model is estimated using pooled maximum likelihood estimation to compute the average long-run estimates and groupspecific short-run coefficients. Therefore, the coefficient of $\gamma i$ is expected to be negative and statistically significant if the model exhibits a usual return to long-run equilibrium. Accordingly, the estimates of PMG parameters are consistent and asymptotically normally distributed for both stationary and non-stationary regressors (Pesaran et al, 1999).

\section{Empirical Findings}

Table 2 reports the Im et al (2003) unit root test results which indicate that SMD, PVR and ER are having unit root problem while BD, IR and BRK are stationary at level. To confirm stationary of variables, the t-statistic in each case should be greater than the critical value at all the conventional levels of significance (1\%, 5\% and 10\%). However, the variables with unit root problem become stationary after first difference. 
Table2: Stationary Test Results

\begin{tabular}{|l|l|l|l|l|}
\hline \multirow{2}{*}{ Variables } & \multicolumn{4}{|l|}{ Im, Pesaran and Shin } \\
\cline { 2 - 5 } & $\begin{array}{l}\text { I(0) with } \\
\text { Constant }\end{array}$ & $\begin{array}{l}\text { I(0) with Constant } \\
\text { \& Trend }\end{array}$ & I(1) with Constant & $\begin{array}{l}\text { I(1) with Constant } \\
\text { \& Trend }\end{array}$ \\
\hline SMD & -1.253 & -1.701 & $-2.987 * * *$ & $-2.998^{* * *}$ \\
\hline PVR & -0.271 & -1.698 & $-4.288^{* * *}$ & $-4.412^{* * *}$ \\
\hline BD & -1.138 & $-2.252^{* *}$ & $-4.203 * * *$ & $-4.145^{* * *}$ \\
\hline ER & -1.282 & -1.805 & $-3.248^{* * *}$ & $-3.239^{* * *}$ \\
\hline IR & $-1.981 * *$ & $-1.859^{*}$ & $-3.744^{* * *}$ & $-4.013^{* * *}$ \\
\hline BRK & -0.809 & $-2.089^{* *}$ & $-4.359^{* * *}$ & $-4.235^{* * *}$ \\
\hline
\end{tabular}

The unit root test shows evidence that the variables are integrated of mix-order thus the pooled mean group (PMG) is presented in Table 3 in order to determine how much of equilibrium is being corrected every year, as well as to examine the long-run relationship among the variables.

\section{Table 3: Pooled Mean Group Estimates}

\begin{tabular}{|c|c|c|c|c|}
\hline Variable & Coefficient & Std. Error & T-Statistic & Prob. \\
\hline \multicolumn{5}{|c|}{ Long-run Equation } \\
\hline PVR & 0.391 & 0.108 & 3.610 & 0.0004 \\
\hline BD & 0.011 & 0.002 & 5.424 & 0.0000 \\
\hline ER & 0.015 & 0.027 & 0.563 & 0.5741 \\
\hline IR & -0.004 & 0.002 & -2.463 & 0.0149 \\
\hline BRK & -0.194 & 0.044 & -4.359 \\
\hline \multicolumn{5}{|c|}{ Short-run Equation } \\
\hline ECT & $\mathbf{- 0 . 1 7 6}$ & $\mathbf{0 . 0 5 1}$ & $\mathbf{- 3 . 4 2 1}$ & $\mathbf{0 . 0 0 0 8}$ \\
\hline PVR & 1.763 & 1.064 & 1.655 & 0.0998 \\
\hline BD & 0.001 & 0.001 & 1.277 & 0.2035 \\
\hline ER & 0.008 & 0.011 & 0.722 & 0.4705 \\
\hline IR & -0.001 & 0.016 & -0.119 & 0.9041 \\
\hline BRK & 0.074 & 0.058 & 1.266 & 0.2074 \\
\hline
\end{tabular}

Note: the poverty reduction variable is in a natural $\log$, Dependent Variable=SMD

As presented in Table 3, the impact of PVR on SMD is positive and statistically significant. The results indicate that a one percent increase in PVR leads to increase of SMD by $0.39 \%$. Although there are no existing empirical studies on poverty reduction-stock market development, it is closely in line with the findings of Baghebo and Emmanuel (2015) that poverty alleviation promotes economic growth. Therefore, when the rate of poverty reduces, there is a likelihood that household will have surplus income to invest in the stock market. The lower the poverty levels of poverty, the more chances of making demand and investment in financial markets that usually lose huge foreign investment in the crisis period. 
Additionally, Sun et al. (2013) assert that poor households with tight financial constraints could not invest in their children education and this can lead to inter-generational poverty. Therefore increasing access to financial resources will magnify economic prospects for the less privileged to fund investment of their children. The findings also support the arbitrage pricing theory (APT) that multiple risk factors predict the stock market returns.

Furthermore, the findings show the control variables are essential in predicting stock market development. The coefficient for BD reveals a significant positive relationship with the SMD. The coefficient reveals that a $1 \%$ increase in BD will bring about $0.011 \%$ increase SMD. This is in support of the complementary hypothesis that stock market and bank are compliments in promoting financial system development in line with the models of Boyd and Smith (1996) and Blackburn et al (2005). Furthermore, the impact ER on SMD is positive and statistically non-significant while the coefficient of interest rates supports the set hypothesis by showing a negative sign and a statistically significant relationship. Furthermore, the results show the existence of a structural break and this indicate the financial crisis has an adverse effect on the African stock markets. Furthermore, the coefficient of the error correction term (ECT)/ speed of adjustment goes in line with the Pesaran et al. (1999) where it is negative and statistically significant. These are necessary to show the rate of convergence to a long-run equilibrium. Hence, the coefficient (-0.176) reveals the disequilibrium that causes the preceding year temporal shock is adjusted by $17.6 \%$ per annum.

Despite the short-run coefficients of the PMG model mostly tell a different story, the relationship between the PVR and SMD is also positive and statistically significant as 1 percent increase in PVR results in an increase of SMD by 1.763 percent at 10 percent significant level. The findings indicate how important and effective is the poverty reduction towards improving the development of the stock market in the selected countries of the African region. Needless to say, however, the other variables of the short-run model do not exert a significant impact on the stock market development. For example, the BD-SMD relationship is positive and not significant at all conventional significant levels. In line with the findings of the long-run estimates, the relationship between ER and SMD is positive and not significant in the short-run. This reveals that in both short and long-run the exchange rate does not matter as far as the development of the stock market is a concern.

Although the IR and SMD are having a negative nexus, it is not as significant as indicated under the long-run model. The structural break due to the global financial crisis does not have an adverse effect on the SMD development under the short-run results. 
Therefore, this paper gives emphasis on the long-run relationship as the pooled mean group (PMG) primary interest is the coefficient of long-run estimates as well as the speed of adjustment which is in line with the Pesaran et al. (1999) theoretical assumption of negative and statistically significant relationship.

Needless to say, to avoid reporting a spurious regression, there is a need for postestimation/diagnostic test to confirm whether there is an issue of the pooled mean group longrun homogeneity restriction, normality and multicollinearity problems in the estimated model. This study employs the Hausman (1978) based test where the null hypothesis reveals that the variation in the coefficients between the mean group (MG) and the pooled mean group (PMG) are statistically similar. Hence the Haussman test chi-square probability value of 0.133 as revealed in table 3 below fail to reject the null hypothesis of poolability. Therefore, the most appropriate estimate for this paper is that of the PMG model which has the validity of the long-run homogeneity restriction.

Table 4: Pooled mean group diagnostic statistics

\begin{tabular}{|c|c|}
\hline Test & P value \\
\hline Hausmann specification test & 0.133 \\
\hline Normality & 0.225 \\
\hline Mean VIF & 2.84 \\
\hline
\end{tabular}

Source: Author's computation

However, the normality distribution of the data which is conducted on the residuals of the model is among the important assumptions of a linear regression thus the data is expected to be normally distributed. Hence the violation of normality assumption leads to the interpretation and inference to be invalid and unreliable (Park, 2008). In fact, for a test to stand for generalization, the data of the series should be distributed normally. Therefore the non-significant probability value of 0.225 as depicted in table 4 indicates the residuals of the model are normally distributed.

In addition, the variance inflation factor (VIF) test was conducted to determine whether the model is free of multicollinearity. The multicollinearity problem occurs when there is a high correlation between one independent variable and others in a model. If an extreme case of multicollinearity (singularity) is detected, Hair et al. (2009) recommend for an omission of the affected variable to guard against reporting an eventual inflation of standard error or resulting to an unreliable regression coefficient. The VIF of this model with an average of 3.47 falls within the range of no multicollinearity problem. Hence the issue of multicollinearity among the series for the model does not have a much concern. In view of the 
diagnostic tests conducted, the results of this paper can be relied upon for policy formulation in the selected African countries on how the stock market can be developed in the continent to promote long-term investment and financial market development.

\section{Conclusion and Policy Implications}

This paper empirically investigates the impact of poverty reduction on the African stock market development using the pooled mean group (PMG) for the sample period of 1996 to 2016. The findings suggest that the poverty reduction exerts a positive impact on stock market development. Therefore, efforts to reduce poverty that is endemic in the region can yield a positive outcome to households through opportunities to invest in the financial market. Consequently, Imai et al (2017) document that over $60 \%$ of the African are below the age of 25 thus the increasing number without corresponding opportunities can aggravate the level of poverty and its attendant consequences thus the fight against poverty reduction in the region should be intensified.Similarly, the global financial crisis represents a major structural change in the African financial market as it impacts negatively on the market development.

There is a need for far-reaching policy reforms that will alleviate poverty, increase financial inclusion and promote rural development so that Africans can have ample opportunity to participate in developing the stock markets that have been small in size and illiquid. It is intuitive to predict that special intervention programs in agricultural and industrial sectors, rural infrastructure, increased access to financial services and human capital development can be among the major drivers of the extreme poverty reduction in the African region. Therefore, attaining a high-income level through poverty alleviation programs promotes savings and investment in stock markets. There is an urgent need for anti-poverty intervention policies and those increasing the financial inclusion of the household to increase their level of income and long-term investment.

The previous literature neglected the relationship between poverty reduction and stock market development hence this paper contributes to filling the identified literature gap. However, the paper is restricted to only 12 out of the 54 African countries due to data availability which makes it challenging to generalize some of the arguments taking into consideration the number of countries in the region. Hence the future research should include more African economies to see how poverty reduction predicts the stock market development. 
Pakistan Journal of Humanities and Social Sciences, 6(3), 2018

\section{References}

Adams, S., Kwame, E. and Klobodu, M. (2016) 'Financial development, control of corruption and income inequality', International Review of Applied Economics. doi: 10.1080/02692171.2016.1208740.

Aduda J, Masila J. M and Onsongo N. (2012) 'The determinants of stock market development: The case for the Nairobi stock exchange', International Journal of Humanities and Social Science, 2(9), pp. 214-230.

Ahmed, S. and Cruz, M. (2016) 'On the impact of demographic change on growth, savings, and poverty', World Development, 105(August), pp. 95-106. doi: 10.1016/j.worlddev.2017.12.018.

Ahuru, R. R. and Olaposi, O. J. (2016) 'The impact of financial liberalization on stock price volatility in Nigeria', International Journal of Advances in Management, Economics and Entrepreneurship, 3(7), pp. 1-6.

Akhter, S. and Daly, K. J. (2009) 'Finance and poverty: Evidence from fixed effect vector decomposition', Emerging Markets Review. Elsevier B.V., 10(3), pp. 191-206. doi: 10.1016/j.ememar.2009.02.005.

Akwara, A., Akwara, N., Enwuchola, J., Adekunle, M. and Udaw, J. (2013) 'Unemployment and poverty: Implications for national security and good governance in Nigeria', International Journal of Public Administration and Management, 2(1), pp. 1-11.

Ali, R. and Afzal, M. (2012) 'Impact of global financial crisis on stock markets: Evidence from Pakistan and India', E3 Journal of Business Management and Economics, 3(7), pp. 275-282. doi: 10.5539/ass.v10n10p86.

Allen, F., Otchere, I. and Senbet, L. (2011) ‘African financial systems : A review', Review of Development Finance. University of Cairo., 1(2), pp. 79-113. doi: 10.1016/j.rdf.2011.03.003.

Amarasinghe, A. A. M. D. (2016) 'A study on the impact of industrial production index ( IPI ) to beverage, food and tobacco sector index with special reference to Colombo Stock Exchange', Italian Oral Surgery. Elsevier Srl, 6(Icsusl 2015), pp. 275-278. doi: 10.1016/j.profoo.2016.02.054.

Arize, A., Kalu, E. and Nkwor, N. (2017) 'Banks versus markets: Do they compete, complement or Co-evolve in the Nigerian financial system? An ARDL approach', Research in International Business and Finance. Elsevier B.V., pp. 1-22. doi: 10.1016/j.ribaf.2017.07.174. 
Asiedu, E. (2002) 'On the Determinants of Foreign Direct Investment to Developing Countries: Is Africa Diffrerent?', World Development, 30(1), pp. 107-19. doi: 10.1016/S0305-750X(01)00100-0.

Asiedu, K. and Afful, K. (2014) 'Stock markets development in Sub-Saharan Africa: Business regulations, governance and fiscal Policy', International Journal of Economics and Finance, 6(1), pp. 15-31. doi: 10.5539/ijef.v6n1p15.

Asiri, B. and Abdalla, M. A. (2015) 'Economic growth and stock market development in Bahrain', Journal of Applied Finance and Banking, 5(2), pp. 67-80.

Baghebo, M. and Emmanuel, N. (2015) 'The impact of poverty alleviation programmes on economic growth in Nigeria 1981 - 2013', International Journal of Humanities and Social Science, 5(10), pp. 177-188.

Batuo, M., Guidi, F. and Mlambo, K. (2010) 'Financial development and income inequality: Evidence from Africa', Munich Personal Repec Archive, (25658).

Beck, T., Demirguc-kunt, A. and Levine, R. (2004) Finance, inequality and poverty: Cross country evidence. 10979.

Beck, T., Demirguc-kunt, A. and Levine, R. (2010) 'Financial institutions and markets across countries and over time: The updated financial development and structure database', The World Bank Research Observer, 24(1), pp. 77-92. doi: 10.1093/wber/lhp016.

Beck, T., Demirgüç-Kunt, A. and Levine, R. (2007) 'Finance, inequality and the poor', Journal of Economic Growth, 12(1), pp. 27-49. doi: 10.1007/s10887-007-9010-6.

Beck, T., Maimbo, S., Faye, I. and Triki, T. (2011) Financing Africa through the crisis and beyond.

Beegle, K., Christiaensen, L., Dabalen, A., \& Gaddis, I. (2016). Poverty in a rising Africa. World Bank Publications.

Blackburn, K., Bose, N. and Capasso, S. (2005) 'Financial development, financial choice and economic growth', Review of Development Economics, 9(2), pp. 135-149. doi: 10.1108/01443580910955033.

Blau, B. M. (2017) 'Economic freedom and crashes in financial markets', Journal of International Financial Markets, Institutions and Money, 47(November), pp. 33-46. doi: 10.1016/j.intfin.2016.11.010.

Boukhatem, J. (2016) 'Assessing the direct effect of financial development on poverty reduction in a panel of low- and middle-income countries', Research in International Business and Finance. Elsevier B.V., 37, pp. 214-230. doi: 
Pakistan Journal of Humanities and Social Sciences, 6(3), 2018

10.1016/j.ribaf.2015.11.008.

Boyd, J. and Smith, B. (1996) 'The Coevolution of the Real and Financial Sectors in the Growth Process', The World Bank Economic Review, 10(2), pp. 371-396. doi: 10.1093/wber/10.2.371.

Chipaumire, G. and Ngirande, H. (2014) 'How stock market liquidity impact economic growth in South Africa', Journal of Economics, 5(2), pp. 185-192.

Clarke, G., Xu, L. and Zou, H. (2006) 'Finance and income inequality: What do the data tell us ?', Southern Economic Journal, 72(3), pp. 578-596.

Collier, P. (2007) 'Poverty reduction in Africa.', Proceedings of the National Academy of Sciences of the United States of America, 104(43), pp. 16763-8. doi: 10.1073/pnas.0611702104.

Das, M. and Mohapatra, S. (2003) 'Income inequality: The aftermath of stock market liberalization in emerging markets', Journal of Empirical Finance, 10(1-2), pp. 217248. doi: 10.1016/S0927-5398(02)00025-7.

Demirgüç-Kunt, A. and Levine, R. (2009) 'Finance and Inequality: Theory and Evidence', Source: Annual Review of Financial Economics, 1(1), pp. 287-318. doi: 10.1146/annurev.financial.050808.114334.

Dhrifi, A. (2013) 'Financial development and poverty: What role for growth and inequality?', International Journal of Academic Research in Economics and Management Sciences, 3(4), pp. 119-129. doi: 10.6007/IJARAFMS/v3-i4/362.

Donou-Adonsou, F., \& Sylwester, K. (2016). Financial development and poverty reduction in developing countries: New evidence from banks and microfinance institutions. Review of Development Finance, 6(1), 82-90.

Ferreira, F., Leite, P. and Ravallion, M. (2010) 'Poverty reduction without economic growth?. Explaining Brazil's poverty dynamics, 1985-2004', Journal of Development Economics. Elsevier B.V., 93(1), pp. 20-36. doi: 10.1016/j.jdeveco.2009.06.001.

Fosu, A. K. (2017) 'Growth, inequality, and poverty reduction in developing countries: Recent global evidence', Research in Economics. Elsevier Ltd, 71(2), pp. 306-336. doi: 10.1016/j.rie.2016.05.005.

Fowowe, B. and Abidoye, B. (2012) 'The effect of financial development on poverty and income inequality in African countries *', The Manchester School. doi: 10.1111/j.1467-9957.2012.02302.x.

Hair, J., Black, W., Babin, B., \& Anderson, R. (2009). Multivariate data analysis (7th ed.). 
Upper Saddle River, NJ: Pearson, New International Edition.

Hausman, J. A. (1978). Specification tests in Econometrics. Econometrica, 46(6), 12511271.http://www.jstor.org/stable/1913827\%0Ahttp://www.jstor.org/stable/1913827

Hearn, B., \& Piesse, J. (2010). Barriers to the development of small stock markets: A case study of Swaziland and Mozambique. Journal of International Development, 22(7), 1018-1037.

Honohan, P. (2004) 'Financial development, growth and poverty: How close are the links?', World Bank Policy Research Working Paper 3203, (3203). Available at: http://www.microfinancegateway.org/gm/document-1.9.26333/21113_wps3203.pdf.

Im, K., Pesaran, M. and Shin, Y. (2003) 'Testing for unit roots in heterogeneous panels', Journal of Econometrics, 115(1), pp. 53-74. doi: 10.1016/S0304-4076(03)00092-7.

Imai, K., Gaiha, R. and Garbero, A. (2017) 'Poverty reduction during the rural-urban transformation: Rural development is still more important than urbanisation', Journal of Policy Modeling. The Society for Policy Modeling, 39(6), pp. 963-982. doi: 10.1016/j.jpolmod.2017.10.002.

Iqbal, B. A. (2010) 'Global financial crisis: Causes, emerging trend and strategy', Business Review, 5(2), pp. 35-50.

Ivanic, M. and Martin, W. (2017) 'Sectoral productivity growth and poverty reduction: National and global impacts', World Development. The Authors, xx. doi: 10.1016/j.worlddev.2017.07.004.

Jauch, S. and Watzka, S. (2015) 'Financial development and income inequality: A panel data approach', Empirical Economics. Springer Berlin Heidelberg. doi: 10.1007/s00181015-1008-x.

Jeanneney, G. and Kpodar, K. (2008) 'Financial development and poverty reduction: Can there be a benefit without a cost?', IMF Working Papers, 08(62), p. 1. doi: 10.5089/9781451869248.001.

Khan, A., Khan, A., Ahmad, A. and Siraj, A. (2011) 'Financial sector development and poverty reduction', Global Journal of Management and Business Research, 11(5).

Kiendrebeogo, Y., Assimaidou, K. and Tall, A. (2017) 'Social protection for poverty reduction in times of crisis', Journal of Policy Modeling. The Society for Policy Modeling, 39(6), pp. 1163-1183. doi: 10.1016/j.jpolmod.2017.09.003.

Kim, D. and Lin, S. (2011) 'Nonlinearity in the financial development - income inequality nexus', Journal of Comparative Economics. Association for Comparative Economic 
Pakistan Journal of Humanities and Social Sciences, 6(3), 2018

Studies, 39(3), pp. 310-325. doi: 10.1016/j.jce.2011.07.002.

Kunieda, T., Okada, K. and Shibata, A. (2014) 'Finance and inequality: How does globalization change their relationship?', Macroeconomic Dynamics, 18(May), pp. 1091-1128. doi: 10.1017/S1365100512000843.

Law, S. and Tan, H. (2009) 'The role of financial development on income inequlity in Malaysia', Journal of Economic Development, 34(2), pp. 153-168.

Lazar, D., Priya, A. J. and Jeyapaul, A. J. (2006) 'Capital Markets and Poverty Alleviation', Asia Pacific Business Review, 2(1), pp. 27-37. doi: 10.1177/097324700600200103.

Levine, R. (2005) 'Finance and growth: Theory and evidence', in Handbook of economic growth, pp. 867-934. doi: 10.1016/S1574-0684(05)01012-9.

Massa, I. (2009). Stock markets in Africa: Bidding for growth amid global turmoil. London: Overseas Development Institute.

Mellor, J. W. and Malik, S. J. (2017) 'The impact of growth in Small commercial farm productivity on rural poverty reduction', World Development. Elsevier Ltd, 91, pp. 110. doi: 10.1016/j.worlddev.2016.09.004.

Montalvo, J. and Ravallion, M. (2010) 'The pattern of growth and poverty reduction in China', Journal of Comparative Economics. Association for Comparative Economic Studies, 38(1), pp. 2-16. doi: 10.1016/j.jce.2009.10.005.

Moya-Martínez, P., Ferrer-Lape, R. and Escribano-Sotos, F. (2015) 'Interest rate changes and stock returns in Spain : A wavelet analysis', BRQ Business Research Quarterly, 18, pp. 95-110. doi: 10.1016/j.brq.2014.07.004.

Naceur, S. and Zhang, R. (2016) Financial development, inequality and poverty: Some international evidence, IMF Working Paper No. 16/32. doi: 10.5089/9781498359283.001.

Odhiambo, N. M. (2009) 'Finance-growth-poverty nexus in South Africa: A dynamic causality linkage', The Journal of Socio-economics, 38, pp. 320-325. doi: 10.1016/j.socec.2008.12.006.

Odhiambo, N. M. (2010) 'Is financial development a spur to poverty reduction? Kenya's experience', Journal of Economic Studies, 37(3), pp. 343-353.

Park, H. (2008). Univariate analysis and normality test using SAS, Stata, and SPSS. Working paper.Indiana University Information Technology Services. Retrieved from http://www.indiana.edu/ statmath/stat/all/normality/index.html

Perez-Moreno, S. (2011) 'Financial development and poverty in developing countries: A 
causal analysis', Empirical Economics, 41(1), pp. 57-80. doi: 10.1007/s00181-0100392-5.

Pesaran, M. H., Shin, Y. and Smith, R. P. (1999) 'Pooled mean group estimation of dynamic heterogeneous panels', Journal of the American Satistical Association, 94(446), pp. 621-634. doi: 10.1080/01621459.1999.10474156.

Pradhan, R., Tripathy, S. and Pandey, S. (2014) 'Banking sector development and economic growth in ARF countries: the role of stock markets', Macroeconomics and Finance in Emerging Market Economies, (July), pp. 37-41. doi: 10.1080/17520843.2014.913071.

Prete, A. L. (2013) 'Economic literacy, inequality, and financial development', Economics Letters. Elsevier B.V., 118(1), pp. 74-76. doi: 10.1016/j.econlet.2012.09.029.

Rashid, A. and Intartaglia, M. (2017) 'Financial development - does it lessen poverty?', Journal of Economic Studies, 44(1), p. doi: http://dx.doi.org/10.1108/JES-06-20150111.

Rewilak, J. (2017) 'The role of financial development in poverty reduction', Review of Development Finance. University of Cairo., 7(2), pp. 169-176. doi: 10.1016/j.rdf.2017.10.001.

Ross, S. A. (1976) 'The Arbitrage Theory of Capital Asset Pricing', Journal of Economic theory, 13, pp. 341-360.

Seven, U. and Coskun, Y. (2016) 'Does financial development reduce income inequality and poverty? Evidence from emerging countries', Emerging Markets Review. Elsevier B.V. doi: 10.1016/j.ememar.2016.02.002.

Sun, P., Sen, S. and Jin, S. (2013) 'Equity market liberalization, credit constraints and income inequality', Economics: The Open-Access, Open-Assessment E-Journal, 7, pp. 0-29. doi: 10.5018/economics-ejournal.ja.2013-12.

Tan, S. and Law, S. (2012) 'Nonlinear dynamics of the finance-inequality nexus in developing countries', Journal of Economic Inequality, pp. 551-563. doi: 10.1007/s10888-011-9174-3.

WDIs. (2016). The World Bank World Development Indicators-World Bank. http://data.worldbank.org/data-catalog/world-developmentindicators

World Bank Group (2015) World Bank. Available at: http://www.worldbank.org. 